\title{
Alpha-synuclein A53T mutation is not frequent on a sample of Brazilian Parkinson's disease patients
}

\author{
Mutação A53T da alfa-sinucleína não é frequente em amostra de população brasileira \\ com doença de Parkinson
}

Gabriela S. Longo', Marcela A. S. Pinhel², Michele L. Gregório³, Bruno A. P. Oliveira², Driele C. G. Quinhoneiro², Waldir A. Tognola', Fábio N. Oliveira', Denise Poltronieri Martins', Sabrina M. Cezario', Caroline L. Sado, Marcelo A. Nakazone ${ }^{1}$, Maria C. J. Calastri, Dorotéia R. S. Souza ${ }^{1}$

\begin{abstract}
Introduction: The pathogenesis of Parkinson's disease (PD) involves both genetic susceptibility and environmental factors, with focus on the mutation in the alpha-synuclein gene (SNCA). Objective: To analyse the polymorphism SNCA-A53T in patients with familial PD (FPD) and sporadic PD (SPD). Method: A total of 294 individuals were studied, regardless of sex and with mixed ethnicity. The study group with 154 patients with PD, and the control group included 140 individuals without PD. The genotyping of SNCA-A53T was performed by PCR/RFLP. Significance level was $p<0.05$. Results: Among all patients, $37(24 \%)$ had FPD and 117 (75.9\%) had SPD. The absence of SNCA-A53T mutation was observed in all individuals. Conclusion: SPD is notably observed in patients. However, the SNCA-A53T mutation was absent in all individuals, which does not differ controls from patients. This fact should be confirmed in a Brazilian study case with a more numerous and older population.
\end{abstract}

Keywords: Parkinson's disease, alpha-synuclein, mutation.

RESUMO

Introdução: A patogênese da doença de Parkinson (DP) envolve fatores ambientais e suscetibilidade genética, destacando-se a mutação de alfa-sinucleína (SNCA.) Objetivos: Analisar a variante genética SNCA-A53T em pacientes com DP familiar (DPF) e DP esporádica (DPE). Método: Foram estudados 294 indivíduos, independente de sexo, com etnia miscigenada, sendo 154 com DP e 140 sem a doença (grupo controle). A genotipagem de SNCA-A53T foi realizada por PCR/RFLP. Nivel de significância para p < 0,05. Resultados: Entre os pacientes, 37(24\%) tinham DPF e 117 (75,9\%) DPE. A ausência da mutação SNCA-A53T em todos os indivíduos. Conclusão: DPE é destacada entre os pacientes, no entanto a mutação SNCA-A53T ausente em todos os indivíduos, não diferenciando os grupo controle e pacientes, o que deve ser confirmado em população brasileira, considerando uma ampla casuística, além da ancestralidade.

Palavras-chave: doença de Parkinson, alfa sinucleína, mutação.

Parkinson's disease (PD) is one of the major degenerative disorders, affecting $2 \%$ of the population over 65 years and up to $4 \%$ in people over 85 years ${ }^{1}$. In Brazil, statistics show that the incidence of PD amounts to $150 / 200$ cases per 100,000 inhabitants². Most cases of PD are idiopathic ${ }^{3}$. However, in approximately $5 \%-10 \%$ of the cases, there is a genetic component with both dominant and recessive inheritance patterns ${ }^{3}$. The chromosomal loci linked to the familial forms of PD are termed PARK1-13. These loci include six autosomal dominant genes [PARK 1or PARK 4 (alpha synuclein - SNCA), PARK 3 (Lewy bodies), PARK 5 (ubiquitin carboxyl-terminal esterase L1 - UCHL1), PARK 8 (leucine-rich repeat kinase 2 - LRRK2) and PARK13 (HTRA serine peptidase 2 - HTRA2)], 4 recessives genes [PARK 2

${ }^{1}$ Faculdade de Medicina de São José do Rio Preto, Sao José do Rio Preto SP, Brazil;

${ }^{2}$ Universidade de São Paulo, Faculdade de Medicina de Ribeirão Preto, Ribeirao Preto SP, Brazil;

${ }^{3}$ Universidade de Franca, Franca SP, Brazil;

${ }^{4}$ Universidade Federal de São Paulo, Sao Paulo SP, Brazil.

Correspondence: Marcela Augusta de Souza Pinhel; Faculdade de Medicina de Ribeirão Preto; Avenida dos Bandeirantes, $3900 ; 14090-900$ Ribeirão Preto SP, Brasil; E-mail: marcelapinhel@yahoo.com.br

Conflict of interest: There is no conflict of interest to declare.

Received 02 July 2014; Received in final form 15 January 2015; Accepted 04 February 2015. 
(parkin - PRKN), PARK 6 (PTEN-induced putative kinase 1 - PINK1), PARK 7 (oncogene DJ1), PARK 9 (ATPase type 13A2 - ATP13A2)] and PARK11 (GIGYF2 - Grb10 Interacting GYF Protein-2), one gene linked to X chromosome (PARK12) and a form with unknown inheritance pattern (PARK10) ${ }^{4,5,6}$. Mutations identified in five major genes were related with genetic etiology of familial PD, such as $a$-synuclein, which mediates autosomal dominant forms of the disease ${ }^{4}$.

The SNCA gene, located on human chromosome 4q21.3-q22, has 7 exons and encodes the a-synuclein protein of 140 amino acids, which is divided into three regions: $\mathrm{N}$-terminal $\alpha$-helical region (where mutations occur in the event of PD); central region (hydrophobic NAC sequence, known as non $\beta$-amyloid component), responsible for the formation of fibrils that cause toxicity; and the acidic C-terminal region $^{5}$. The analysis of the sequence of exon 4 revealed that a single change of $\mathrm{G} \rightarrow \mathrm{A}$ (Guanine $\rightarrow$ Adenine) in the position 209 of the nucleotide chain causes the amino acid alanine to be replaced by the amino acid threonine at position 53 of the $\alpha$-synucleinprotein 6 .

The $\alpha$-synuclein protein is the major protein component of intracellular neuron deposits observed in $\mathrm{PD}^{7}$. Although the function and the underlying dysregulation of SNCA mechanisms are not fully understood, the formation and expression of oligomers of this protein play a critical role in the development of the disease ${ }^{8}$. This wildtype $\alpha$-synuclein protein is the major component of LB, in both familial and sporadic PD, which highlights the role of the SNCA gene variant in all presentations of the disease $^{9}$. Functionally, relevant genetic variants in and near the SNCA gene are risk factors for sporadic PD (SPD). For example, the A53T mutation promotes greater aggregation and fibrillation in the LBs, and interferes with neurotransmission ${ }^{9}$, which confirms its role in the pathogenesis of the disease.

Therefore, this study aimed to analyse the frequency of the genetic variant SNCA-A53T in a Brazilian population with familial PD (FPD) or sporadic PD.

\section{METHOD}

A total of 294 individuals divided into two groups were studied: Study Group with 154 PD patients and Control Group formed by140 subjects, who had not been diagnosed with PD. The study group included PD patients older than 50 years, regardless of ethnicity ${ }^{10}$ and sex. The patients were examined at the Outpatient Clinic for Movement Disorders of Hospital de Base, Medical School of São José do Rio Preto.

Diagnosis of PD followed the criteria recommended by Jankovic ${ }^{11}$, including bradykinesia, rigidity, resting tremor, postural instability, unilateral onset, L-dopa response for more than five years, levodopa-induced dyskinesia, progressive disorder, persistent asymmetry and clinical course of ten years or more, as well as complementary tests. The Control Group was selected in ambulatory clinics of that institution, namely, orthopedics, gynecology, among others. All subjects were informed about the study and confirmed their willingness to participate by signing an informed consent form. The study was approved by the Ethics Research Committee of institution.

The subjects were studied considering allele and genotypic frequencies for theSNCA-A53T mutation. Blood was collected by venepuncture with EDTA, and the genomic DNA was extracted from whole blood $(5 \mathrm{~mL})$ following the salting-out method ${ }^{12}$. PCR amplification of DNA was performed in a thermocycler (Eppendorf - Mastercycler). Each tube included $0.5 \mathrm{~mL}$ of each deoxynucleotide $(0.8 \mathrm{mM})$; 2.5mLof10 X PCR buffer; $2.5 \mathrm{~mL}$ of $10 \%$ dimethyl sulfoxide; $2.5 \mathrm{~mL}$ of each primer $(2.5 \mathrm{mM}) ; 0.2 \mathrm{~mL}$ of Taq polymerase (5U/mL); $11 \mathrm{~mL}$ of Milli Q water; $2 \mathrm{~mL}$ of genomic DNA dilution $(0.2 \mathrm{mg})$. For the PCR, the following primer sequences were used: (exon 4): P1- 5' GCT AAT CAG CAA TTT AAG GCT AG 3'; P2- 5' GAT ATG TTC TTA GAT GCT CAG 3'. The initial DNA denaturation was achieved at $94^{\circ} \mathrm{C}$ for 4 minutes. Next, the reaction mixture was subjected to 35 cycles of $94^{\circ} \mathrm{C}$ for 20 seconds and of $55^{\circ} \mathrm{C}$ for 30 seconds, to an extension at $72^{\circ} \mathrm{C}$ for 45 seconds, and to a final cycle at $72^{\circ} \mathrm{C}$ for 10 minutes $^{13}$. The post PCR product was digested with the restriction enzyme Tsp45I at $37^{\circ} \mathrm{C}$ for 4 hours and coloured by GelRed ${ }^{\circ}$ (Uniscience). Electrophoresis was performed in $1 \%$ agarose gel at constant current of $100 \mathrm{~V}$ during 40 minutes, in order to separate fragments of $88 \mathrm{pb}$, $128 \mathrm{pb}$ and $216 \mathrm{pb}$ in the presence of mutation (AG); $216 \mathrm{pb}$ for homozygous wild-type (GG) as well as $88 \mathrm{pb}$ and $128 \mathrm{pb}$ for homozygous mutant (AA). A sample of standard DNA (100bp Invitrogen) was used for comparison of the electrophoretic bands (Figure).

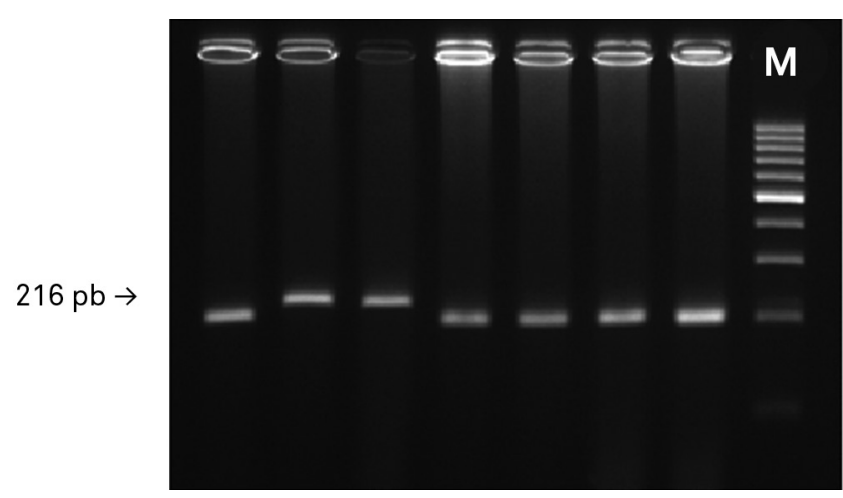

Figure. Diagram presents electrophoretic profile in $1 \%$ agarose gel for alpha-synuclein mutation, showing wild-type homozygous genotype (GG) on DNA fragments of 216 base pairs (bp). $M=$ Molecular weight marker of $100 \mathrm{bp}$ (Synapse Biotechnology). 
The quantitative and qualitative analysis was performed by t-test and Chi-square test, respectively, with the use of the MiniTab14 and GraphPad3 software. The adopted level of significance was $\mathrm{p}<0.05$.

\section{RESULTS}

Table shows demographic data and history of PD patients. The mean age was $67.9 \pm 11.5$ years in the study group, and $51.0 \pm 20.4$ years in the control group $(\mathrm{p}<0.0001)$. The study included only those patients with disease duration longer than 10 years.

There was a prevalence of males in the study group $(\mathrm{N}=95 ; 61.6 \%)$ compared with the control group $(\mathrm{N}=55 ; 39.2 \% \%$; $\mathrm{p}=0.0002)$. In the study group, 37 patients $(24.0 \%)$ showed history of familial PD versus 117 patients (75.9\%) with sporadic PD.

Patients were qualified as familial, when they had at least one relative of first degree diagnosed with PD, regardless of Mendelian pattern of inheritance. Sporadic cases included individuals without any family history of the disease in the past three generations.

The genome analysis of all patients and controls showed homozygous wild-type genotype (GG), which demonstrates the absence of SNCA-A53T mutation in both groups.

\section{DISCUSSION}

This study has not found any association of A53T mutation in the SNCA gene with Parkinson's disease. This corroborates the data presented by Moura et al. ${ }^{14}$, who conducted research on Brazilian populations and quantified the $S N C A$ gene mutations without finding any alterations. SNCA multiplications have been implicated in autosomal dominant forms of PD since $2003^{15}$. However, it became clear that whole-gene multiplications in SNCA locus are a rare form of parkinsonism and may account for only a small fraction of the total number of PD patients ${ }^{16,17}$.

Remarkably, further Brazilian studies found no SNCA-A53T mutation in PD patients ${ }^{14,18,19}$. Furthermore, other genes related to $\mathrm{PD}$, such as APOE, GSTS and LRRK2 (PARK8), also showed no difference between patients and controls in this population ${ }^{20,21,22,23}$. On the other hand, mutations in the genes GIGYF (PARK11), ATP13A2 (PARK9) and $G B A$ were associated with $\mathrm{PD}^{6}$.

Vaughan et al. ${ }^{13}$ evaluated 7 exons of $S N C A$ gene in 30 European and American children with autosomal dominant PD, who did not show either A53T mutation or other mutations. Another study, also with PD patients, did not confirm the presence of this genetic variant in the SNCA gene $^{24}$. Moreover, Athanassiadou et al..$^{25}$ assessed 19 families with no biological relations, where at least two relatives of first/second degree were affected with PD. The authors
Table. Patients with Parkinson's disease (PD) and Controls, considering sex, age and family history for PD.

\begin{tabular}{|c|c|c|c|c|c|}
\hline \multirow{2}{*}{$\begin{array}{l}\text { Variable } \\
\text { Sex }\end{array}$} & \multicolumn{2}{|c|}{$\mathrm{PD}(\mathrm{N}=154)$} & \multicolumn{2}{|c|}{ Controls $(N=140)$} & \multirow[t]{2}{*}{$p$} \\
\hline & $\mathrm{N}$ & $\%$ & $\mathrm{~N}$ & $\%$ & \\
\hline Female & 59 & 38.3 & 85 & 60.7 & $0.0002^{*}$ \\
\hline Male & 95 & 61.7 & 55 & 39.3 & \\
\hline \multirow{2}{*}{ Age (years) } & $M$ & SD & $M$ & SD & $\mathrm{pt}$ \\
\hline & 67.9 & 11.5 & 51.0 & 20.4 & $<0.0001 \dagger$ \\
\hline Family History & $\mathrm{N}$ & $\%$ & $\mathrm{~N}$ & $\%$ & \\
\hline Yes & 37 & 24.0 & 0 & 0 & -- \\
\hline No & 117 & 75.9 & 0 & 0 & \\
\hline
\end{tabular}

p: Fisher's Exact Test or Chi-Square Test (X2); pt: t-test; $p$ : Significance level.

observed the presence of the mutation in several members of those 7 families, showing autosomal dominant inheritance pattern. Choi et al. ${ }^{26}$ identified the A53T mutation in only 1 of 72 patients with early-onset PD, whose family history was consistent with autosomal dominant PD.

In this study, the selected population was of mixed ethnicity $^{10}$, unlike the population in which the SNCA-A53T mutation was found ${ }^{27}$. Furthermore, in this study, control subjects, without a family history of PD, were selected from other speciality clinics, which made it difficult to perform matching pair analysis on sex and age with the group of patients. This may be a limitation of this study. Elderly individuals (> 60 years) have been treated in the several speciality clinics of the hospital and showed other neurodegenerative diseases, which were considered as exclusion criteria for this study.

However, these discrepancies seem to have little relevance, considering the absence of said mutation in both groups, which seems to be different in the Brazilian population $^{14,18,19}$. Additionally, individuals remained in the control group, regardless of the matching pair analysis with patients, which enabled a larger number of individuals to perform comparative analysis.

Mutations in the SNCA gene enhance the production of alpha-synuclein protein, which contributes to the pathogenesis of $\mathrm{PD}^{28}$. SNCA is expressed throughout the brain, specially in presynaptic nerve terminals, and SNCA-A53T rather tends to form aggregates there are critical to Lewy bodies formation, both familial and idiopathic PD. This aggregation of SNCA is thought to be a key occurence in dopaminergic neuronal cell loss ${ }^{3,29}$. The role of SNCA under normal physiological conditions is not yet completely clear, although there is evidence that implicates SNCA in neurotransmitter release and vesicle turnover at the presynaptic terminals ${ }^{30}$.

However, this study conducted in a population of mixed ethnicity showed that both FPD and SPD are not associated with SNCA-A53T, which suggests the need for further evaluation and identification of larger and specific risk subgroups. Also, understanding the molecular mechanisms involved in its development will contribute to the application of molecular therapy interventions. 


\section{References}

1. Tan YY, Wu L, Zhao ZB, Whang Y, Xiao Q, Liu J et al. Methylation of $\alpha$-synuclein and leucine-rich repeat kinase 2 in leukocyte DNA of Parkinson's disease patients. Parkinsonism Relat Disord. 2014;20(3):308-13. http://dx.doi.org/10.1016/j.parkreldis.2013.12.002

2. Ministério da Saúde. Secretaria de Atenção à Saúde. Protocolo clínico e diretrizes terapêuticas. Doença de Parkinson. Available at: http://portalsaude.saude.gov.br/images/pdf/2014/setembro/19/ pcdt-parkinson-republicado-2010.pdf. Accessed (April, 13, 2013).

3. Coppedè F. Genetics and epigenetics of Parkinson's disease. ScientificWorldJournal. 2012;2012:489830. http://dx.doi.org/10.1100/2012/489830.

4. Klein C, Westenberger A. Genetics of Parkinson's disease. Cold Spring Harb Perspect Med. 2012;2(1): a008888. http://dx.doi.org/10.1101/cshperspect.a008888.

5. Sironi F, Primignani P, Ricca S, Tunesi S, Zini M, Tesei S et al. DJ1 analysis in a large cohort of Italian early onset Parkinson Disease patients. Neurosci Lett. 2013;557(Pt B):165-70. http://dx.doi. org/10.1016/j.neulet.2013.10.048

6. Santos AV, Pestana CP, Diniz KR, Campos M, Abdalla-Carvalho $\mathrm{CB}$, Rosso AL et al. Mutational analysis of GIGYF2, ATP13A2 and GBA genes in Brazilian patients with early-onset Parkinson's disease. Neurosci Lett. 2010;485(2):121-4. http://dx.doi.org/10.1016/j.neulet.2010.08.083

7. Breydo L, Reddy KD, Piai A, Felli IC, Pierattelli R, Uversky VN. The crowd you're in with: effects of different types of crowding agents on protein aggregation. Biochim Biophys Acta. 2014; 1844(2):346-57. http://dx.doi.org/10.1016/j.bbapap.2013.11.004

8. Kalia LV, Kalia SK, McLean PJ, Lozano AM, Lang AE. $\alpha$-Synuclein oligomers and clinical implications for Parkinson disease. Ann. Neurol. 2013;73(2):155-69. http://dx.doi.org/10.1002/ana.23746

9. Sun F, Kanthasamy A, Anantharam V, Kanthasamy AG. Environmental neurotoxic chemicals-induced ubiquitin proteasome system dysfunction in the pathogenesis and progression of Parkinson's disease. Pharmacol Ther. 2007;114(3):327-44. http://dx.doi.org/10.1016/j.pharmthera.2007.04.001

10. Parra FC, Amado RC, Lambertucci JR, Rocha J, Antunes CM, Pena SD. Color and genomic ancestry in Brazilians. Proc Natl Acad Sci USA 2003; 100(1):177-82. http://dx.doi.org/10.1073/pnas.0126614100

11. Jankovic J. Parkinson's disease: clinical features and diagnosis. J Neurol Neurosurg Psychiatry. 2008; 79(4):368-76. http://dx.doi.org/10.1136/jnnp.2007.131045

12. Salazar LA, Hirata MH, Cavalli SA, Machado MO, Hirata RD. Optimized procedure for DNA isolation from fresh and cryopreserved clotted human blood useful in clinical molecular testing. Clin.Chem. 1998;44(8):1748-50.

13. Vaughan JR, Farrer MJ, Wszolek ZK, Gasser T, Durr A, Agid $Y$ et al. Sequencing of the a-synuclein gene in a large series of cases of familial Parkinson's disease fails to reveal any further mutations. Hum Mol Genet. 1998;7(4):751-3. http://dx.doi.org/10.1093/hmg/7.4.751

14. Moura KC, Campos Junior M, Rosso AL, Nicaretta DH, Pereira JS, Silva DJ et al. Exon dosage variations in Brazilian patients with Parkinson's disease: analysis of SNCA, PARKIN, PINK1 and DJ-1 genes. Dis Markers. 2012;32(3):173-8. http://dx.doi.org/10.3233/DMA-2011-0873

15. Singleton AB, Farrer M, Johnson J, Singleton A, Hague $S$, Kachegurs $J$ et al. alpha-Synuclein locus triplication causes Parkinson's disease. Science. 2003;302(5646):841. http://dx.doi.org/10.1126/science.1090278
16. Nuytemans K, Theuns J, Cruts M, Van Broeckhoven C. Genetic etiology of Parkinson disease associated with mutations in the SNCA, PARK2, PINK1, PARK7, and LRRK2 genes: a mutation update. Hum Mutat. 2010;31(7):763-80. http://dx.doi.org/10.1002/humu.21277

17. Ross OA, Braithwaite AT, Skipper LM, Kachergus J, Hulihan MM, Middleton FA et al. Genomic investigation of alpha-synuclein multiplication and parkinsonism. Ann Neurol. 2008;63(6):743-50. http://dx.doi.org/10.1002/ana.21380

18. Teive HA, Raskin S, Iwamoto FM, Germiniani FM, Baran MH, Werneck LC et al. The G209A mutation in the alpha-synuclein gene in Brazilian families with Parkinson's disease.Arq Neuropsiquiatr.2001;59(3B):722-4. http://dx.doi.org/10.1590/S0004-282X2001000500013

19. Camargos ST, Dornas LO, Momeni P, Lees A, Hardy J, Singleton A et al. Familial Parkinsonism and early onset Parkinson's disease in a Brazilian movement disorders clinic: phenotypic characterization and frequency of SNCA, PRKN, PINK1, and LRRK2 mutations. Mov Disord. 2009;24(5):662-6. http://dx.doi.org/10.1002/mds.22365

20. Munhoz RP, Wakutani Y, Marras C, Teive HÁ, Raskin S, Werneck LC et al. The G2019S LRRK2 mutation in Brazilian patients with Parkinson's disease: phenotype in monozygotic twins. Mov Disord. 2008;23(2):290-4. http://dx.doi.org/10.1002/mds.21832

21. Gregório ML, Pinhel MA, Sado CL, et al. Impact of genetic variants of apolipoprotein $\mathrm{E}$ on lipid profile in patients with Parkinson's disease. BioMed Res Int. 2013;2013:641515. http://dx.doi.org/10.1155/2013/641515

22. Pinhel MA, Sado CL, Longo GS, Gregório ML, Amorim GS, Florim GM et al. Nullity of GSTT1/GSTM1 related to pesticides is associated with Parkinson's disease. Arq Neuropsiquiatr. 2013;71(8):527-32. http://dx.doi.org/10.1590/0004-282X20130076

23. Longo GS, Pinhel MS, Sado CL, Gregório ML, Amorim GS, Florim GS et al. Exposure to pesticides and heterozygote genotype of GSTP1-Alw26I are associated to Parkinson's disease. Arq Neuropsiquiatr. 2013;71(7):446-52. http://dx.doi.org/10.1590/0004-282X20130060

24. Farrer M, Wavrant-De Vrieze F, Crook R, Boles L, Perez-Tur J, Hardy $\mathrm{J}$ et al. Low frequency of alpha-synuclein mutations in familial Parkinson's disease. Ann Neurol. 1998;43(3):394-7.

25. Athanassiadou A, Voutsinas G, Psiouri L, Leroy E, Polymeropoulos $\mathrm{MH}$, Ilias A et al. Genetic analysis of families with Parkinson disease that carry the Ala53Thr mutation in the gene encoding alpha-synuclein. Am J Hum Genet. 1999;65(2):555-8. http://dx.doi.org/10.1086/302486

26. Choi JM, Woo MS, Ma HI, Kang SY, Sung YH, Yong SW et al. Analysis of PARK genes in a Korean cohort of early-onset Parkinson disease. Neurogenetics. 2008;9(4):263-9. http://dx.doi.org/10.1007/s10048-008-0138-0

27. Ki CS, Stavrou EF, Davanos N, Lee WY, Chung EJ, Kim JY et al. The Ala53Thr mutation in the alpha-synuclein gene in a Korean family with Parkinson disease. Clin Genet. 2007;71(5):471-3. http://dx.doi.org/10.1111/j.1399-0004.2007.00781.x

28. Nishioka K, Ross OA, Ishii K, Kachegus JM, Ishiwata K, Kitagawa $\mathrm{M}$ et al. Expanding the clinical phenotype of SNCA duplication carriers. Mov Disord. 2009;24(12):1811-9. http://dx.doi.org/10.1002/mds.22682

29. Bourdenx M, Bezard E, Dehay B. Lysosomes and $\alpha$-synuclein form a dangerous duet leading to neuronal cell death. Front Neuroanat. 2014;8:83. http://dx.doi.org/10.3389/fnana.2014.00083

30. Liu S, Ninan I, Antonova I, Battaglia F, Trinchese F, Narasanna A et al. alpha-Synuclein produces a long-lasting increase in neurotransmitter release. EMBO J. 2004;23(22):4506-16. http://dx.doi.org/10.1038/sj.emboj.7600451 
Arquivos de Neuro-Psiquiatra 2015;73(6):506-509.

In Page 506, the name of the authors where is written:

Gabriela S. Longo ${ }^{1}$, Marcela A. S. Pinhel ${ }^{2}$, Michele L. Gregório ${ }^{3}$, Bruno A. P. Oliveira ${ }^{2}$, Driele C. G. Quinhoneiro ${ }^{2}$, Waldir A. Tognola ${ }^{1}$, Fábio N. Oliveira ${ }^{1}$, Sabrina M.Cezario ${ }^{1}$, Caroline L. Sado ${ }^{4}$, Marcelo A. Nakazone ${ }^{1}$, Maria C. J. Calastri ${ }^{1}$, Dorotéia R. S. Souza ${ }^{1}$

It should be:

Gabriela S. Longo ${ }^{1}$, Marcela A. S. Pinhel ${ }^{2}$, Michele L. Gregório³, Bruno A. P. Oliveira², Driele C. G. Quinhoneiro², Waldir A. Tognola ${ }^{1}$, Fábio N. Oliveira ${ }^{1}$, Denise Poltronieri Martins ${ }^{1}$, Sabrina M. Cezario ${ }^{1}$, Caroline L. Sado ${ }^{4}$, Marcelo A. Nakazone ${ }^{1}$, Maria C. J. Calastri ${ }^{1}$, Dorotéia R. S. Souza ${ }^{1}$ 